\title{
Proportion and Characteristics of Insomnia among Lecturers Continuing Postgraduate Education at the Faculty of Medicine Udayana University
}

\author{
Ni Putu Kostarika Melia Daradila ${ }^{1}$, Desak Ketut Indrasari Utami², \\ Kumara Tini ${ }^{3}$, I Putu Eka Widyadharma ${ }^{4}$ \\ ${ }^{1}$ Faculty of Medicine, Udayana University, Denpasar, Indonesia \\ 2, 3, ${ }^{4}$ Department of Neurology, Faculty of Medicine, Udayana University, Denpasar, Indonesia \\ Corresponding Author: Desak Ketut Indrasari Utami
}

\begin{abstract}
Fatigue and work stress can trigger insomnia. Insomnia is the most common sleep disorder with a prevalence of $10-30 \%$ in the world population. One of the professions that are prone to work burnout are lecturers, especially lecturers who are currently pursuing postgraduate education. These lecturers have two roles, namely as educators and college students, so they have a fairly solid task. This study aims to determine the proportion and characteristics of insomnia in lecturers who continue their postgraduate education at the Faculty of Medicine. This research is a descriptive observational study with a crosssectional approach. The data collection technique was carried out by total sampling by distributing questionnaires to lecturers who continuing postgraduate education at the Faculty of Medicine. This study involved 41 subjects who met the inclusion and exclusion criteria. Of all subjects, $24.4 \%$ had mild insomnia, the rest did not experience insomnia. Mild insomnia is most common in the early adult age group, with more frequent in males than females. Subject have varying stress levels. More obese and do not apply sleep hygiene. All subjects do not smoke, most do not consume coffee and alcohol. In conclusion, the proportion of insomnia among lecturers who continue their postgraduate education at the Faculty of Medicine is $24.4 \%$ with mild insomnia category. Mild insomnia is more common in male lecturers in early adulthood with varying levels of stress and most of them are obese and do not apply sleep hygiene.
\end{abstract}

Keywords: [Insomnia, Lecturer, Student, Postgraduate]

\section{INTRODUCTION}

Insomnia is the most common sleep disorder with a prevalence of $10-30 \%$ in the world population. ${ }^{[1,2]}$ According to the third edition of the International Classification of Sleep Disorders (ICSD-3), insomnia is characterized by persistent difficulty initiating sleep, dissatisfaction with sleep consolidation due to prolonged awakening despite adequate opportunities and circumstances for sleep, and results in some form of daytime dysfunction lasting at least three nights per week for a minimum of three months. ${ }^{[3]}$ Insomnia is associated with clinically significant distress that adversely affects health and decreases quality of life such as signs of stress, fatigue, daytime sleepiness, decreased cognitive function, poor academic performance, decreased productivity at work, and irritability. ${ }^{[4,5]}$

In India, it was found that $33 \%$ of adults experienced chronic insomnia in 2015. [6] A meta-analysis study in China found that younger adults have a higher risk of experiencing insomnia than older adults because fatigue and work stress in the digitalization era can disrupt biological sleep time and cause insomnia. [7] Field findings on postgraduate students in Indonesia said that study assignments resulted in poor physical activity which 
affected the severity of insomnia and could indirectly reduce quality of life. ${ }^{[8]}$

In terms of work, the education sector causes a lot of work burnout and one of the professions is lecturers, especially lecturers who continue their postgraduate education. These lecturers have two roles, namely as educators and college students, who in carrying out their obligations must also adhere to the "Tri Dharma Perguruan Tinggi" such as education, research, and community service so they have fairly solid task. [9] This can cause new stress for lecturers who continue their postgraduate education. The response to stressful situations can cause insomnia and in the long term can cause hormonal imbalances that pose a risk to health. ${ }^{[10,11]}$ Considering this is quite important to do as an effort to maintain the quality of the human resources produced. This study was designed to determine the proportion and characteristics of insomnia among lecturers continuing postgraduate education.

\section{MATERIALS \& METHOD}

The design of this study is descriptive observational with a crosssectional approach. This study carried out for 3 months (March-May 2021) by collecting primary data in the form of questionnaires distributed via Google Form and paper with purposive sampling technique. The questionnaire is divided into 3 parts:

1. Subject's biodata section which includes name, age, gender, height, and weight.

2. The characteristics analysis section in the form of sleep hygiene, alcohol consumption habits (defined as consuming alcohol in the past week), coffee consumption habits (defined as consuming coffee $\geq 1$ time a day), active smoking habits.

3. The Insomnia Severity Index Questionnaire section, which has been validated in Indonesia, consists of 7 questions each rated on a 0-4 scale based on symptoms and consequences of insomnia over the past 2 weeks. The higher score shows a higher incidence of insomnia.

4. The DASS-21 Questionnaire section, is a set of three self-report scales designed to measure the negative emotional states, consists of 7 items on each scale. This study only measures the stress scale.

Questionnaires were distributed to lecturers who are continuing their postgraduate education at the Faculty of Medicine, Udayana University. The inclusion criteria in this study were active lecturers who were willing to fill out the questionnaire completely after agreeing to the informed consent. Meanwhile, incomplete data were excluded. The data that has been collected is then analysed univariate to determine the distribution of the frequency and proportion of the characteristics of each variable studied, such as the severity of insomnia, age, gender, stress level, BMI, sleep hygiene, alcohol consumption, coffee consumption, smoking. Furthermore, the data obtained are presented in the form of a frequency distribution table and the percentage of the variables studied.

\section{RESULT}

The characteristics of research subjects are shown in Table 1. Insomnia is most commonly found in the late adult age group (58.5\%), followed by early adulthood (26.8\%), and early elderly (14.6\%). Gender was mostly male (61\%) than female. Stress levels vary, but are dominated by the normal category (82.9\%). In term of stress level and body mass index, most of them were normal, followed by overweight (29.3\%), obese (26.8\%) and underweight (2.4\%). Most subjects applied sleep hygiene (58.5\%). The habit of alcohol consumption is dominated by those who did not consume alcohol at all (87.8\%). More subjects had the habit of consuming coffee $(70.7 \%)$ than those who did not consume coffee. All subjects did not have the habit of smoking. 
Ni Putu Kostarika Melia Daradila et.al. Proportion and characteristics of insomnia among lecturers continuing postgraduate education at the faculty of Medicine Udayana University.

Table 1. Characteristics of Research Subjects

\begin{tabular}{|c|c|c|c|}
\hline Characteristics of Research Subjects & & $\mathbf{N}$ & $\%$ \\
\hline Age & Sub-Group & & \\
\hline Early Adulthood & $26-35$ years old & 11 & 26.8 \\
\hline Late Adulthood & $36-45$ years old & 24 & 58.5 \\
\hline Early Elderly & $46-55$ years old & 6 & 14.6 \\
\hline Late Elderly & $56-65$ years old & 0 & 0 \\
\hline Seniors & $>65$ years old & 0 & 0 \\
\hline \multicolumn{4}{|l|}{ Gender } \\
\hline Man & & 25 & 61 \\
\hline Female & & 16 & 39 \\
\hline \multicolumn{4}{|l|}{ Stress Level } \\
\hline Normal & & 34 & 82.9 \\
\hline Mild & & 1 & 2.4 \\
\hline Moderate & & 4 & 9.8 \\
\hline Severe & & 2 & 4.9 \\
\hline \multicolumn{4}{|l|}{ Body Mass Index (BMI) } \\
\hline Extremely Underweight & $<17.0\left(\mathrm{~kg} / \mathrm{m}^{2}\right)$ & 0 & 0 \\
\hline Underweight & $\geq 17.0-<18,5\left(\mathrm{~kg} / \mathrm{m}^{2}\right)$ & 1 & 2.4 \\
\hline Normal & $\geq 18.5-<25\left(\mathrm{~kg} / \mathrm{m}^{2}\right)$ & 17 & 41.5 \\
\hline Overweight & $\geq 25-<27\left(\mathrm{~kg} / \mathrm{m}^{2}\right)$ & 12 & 29.3 \\
\hline Obese & $\geq 27\left(\mathrm{~kg} / \mathrm{m}^{2}\right)$ & 11 & 26.8 \\
\hline \multicolumn{4}{|l|}{ Sleep Hygiene } \\
\hline Yes & & 24 & 58.5 \\
\hline No & & 17 & 41.5 \\
\hline \multicolumn{4}{|l|}{ Alcoholic Drinks/week } \\
\hline Drink in the past week & & 0 & 0 \\
\hline None in the past week & & 5 & 12.2 \\
\hline Non-drinker & & 36 & 87.8 \\
\hline \multicolumn{4}{|l|}{ Coffee Consumptions/day } \\
\hline Yes & & 29 & 70.7 \\
\hline No & & 12 & 29.3 \\
\hline \multicolumn{4}{|l|}{ Smoked Cigarettes } \\
\hline Smokers & & 0 & 0 \\
\hline Non-smokers & & 41 & 100 \\
\hline
\end{tabular}

Table 2. Proportion of Insomnia

\begin{tabular}{|l|l|l|}
\hline Tingkat Insomnia & N & \% \\
\hline No Clinically Significant Insomnia & 31 & 75.6 \\
\hline Mild/Subthreshold Insomnia & 10 & 24.4 \\
\hline Moderate Severity Insomnia & 0 & 0 \\
\hline Severe Insomnia & 0 & 0 \\
\hline Total & 41 & 100.0 \\
\hline
\end{tabular}

Table 3. Characteristics of Mild Insomnia

\begin{tabular}{|l|l|l|l|}
\hline Characteristics of Research Subjects & N & $\%$ \\
\hline Age & Sub-Group & & \\
\hline Early Adulthood & $26-35$ years old & 6 & 60 \\
\hline Late Adulthood & $36-45$ years old & 4 & 40 \\
\hline Early Elderly & $46-55$ years old & 0 & 0 \\
\hline Late Elderly & $56-65$ years old & 0 & 0 \\
\hline Seniors & $>65$ years old & 0 & 0 \\
\hline Gender & \multicolumn{3}{|l|}{} \\
\hline Man & & 6 & 60 \\
\hline Female & & 4 & 40 \\
\hline Stress Level & & & \\
\hline Normal & & 5 & 50 \\
\hline Mild & & 0 & 0 \\
\hline Moderate & 3 & 30 \\
\hline Severe & 2 & 20 \\
\hline Body Mass Index (BMI) & \multicolumn{3}{|l}{} \\
\hline Extremely Underweight & $<17.0\left(\mathrm{~kg} / \mathrm{m}^{2}\right)$ & 0 & 0 \\
Underweight & $\geq 17.0-<18,5\left(\mathrm{~kg} / \mathrm{m}^{2}\right)$ & 1 & 10 \\
\hline Normal & $\geq 18.5-<25\left(\mathrm{~kg} / \mathrm{m}^{2}\right)$ & 2 & 20 \\
\hline Overweight & $\geq 25-<27\left(\mathrm{~kg} / \mathrm{m}^{2}\right)$ & 2 & 20 \\
\hline Obese & $\geq 27\left(\mathrm{~kg} / \mathrm{m}^{2}\right)$ & 5 & 50 \\
\hline Sleep Hygiene & & & \\
\hline Yes & & 4 & 40 \\
\hline No & & 6 & 60 \\
\hline Alcoholic Drinks/week & & 0 & 0 \\
\hline Drink in the past week & & 2 & 20 \\
\hline None in the past week & 8 & 80 \\
\hline Non-drinker & & & \\
\hline & & & \\
\hline
\end{tabular}


Ni Putu Kostarika Melia Daradila et.al. Proportion and characteristics of insomnia among lecturers continuing postgraduate education at the faculty of Medicine Udayana University.

\begin{tabular}{|c|c|c|}
\hline \multicolumn{3}{|c|}{ Table 3 Continued... } \\
\hline Coffee Consumptions/day & & \\
\hline Yes & 3 & 30 \\
\hline No & 7 & 70 \\
\hline Smoked Cigarettes & & \\
\hline Smokers & 0 & 0 \\
\hline Non-smokers & 10 & 100 \\
\hline
\end{tabular}

Table 2. shows the proportion of the incidence of insomnia from 41 subjects who had mild insomnia was 10 subjects (24.4\%), the rest did not experience insomnia. In addition, there were no subjects who experienced moderate or severe insomnia.

Based on Table 3. the characteristics of mild insomnia are dominated by male lecturers with early adulthood, obese, and do not apply sleep hygiene. There are subjects with moderate and severe stress levels. Levels of coffee and alcohol consumption tend to be low. In addition, all subjects do not have a smoking habit.

\section{DISCUSSION}

In our current study of 41 lecturers, the proportion of insomniacs was $24.4 \%$ and the overall category was mild insomnia. Subject with mild insomnia were found to be higher in early adulthood (60\%). This is in line with research in Indonesia reported by Nurdin that insomnia was more common in early adulthood. ${ }^{[8]} \mathrm{A}$ study in the US by DiBonaventura et al. found insomnia to be higher at a younger age. ${ }^{[12]}$ Graduate college students in the early adult group belong to the productive age stage. This stage deals with the way individuals solve problems. Sometimes there is a feeling of wanting to prolong adolescence and not wanting to have the responsibilities of an adult. Early adulthood is a transition period from late adolescence to late adulthood where there is a process of adjustment and development of demands. ${ }^{[13]}$ Research in the UK by Armstrong et al. found that sleep disturbances due to anxiety were highest during the early adulthood phase, while there were different reasons and patterns in the elderly which tended to be caused by disease factors experienced. ${ }^{[14]}$

Lecturers with insomnia in this study were dominated by men. This is in line with research in Indonesia reported by Sumedi and Kuswati that are more dominant in men that woman with complaints it is easier to wake up at night. ${ }^{[15]}$ In addition, men with insomnia were also found to have poor lifestyle factors. [16] However, a metaanalysis study in 2020 found that women are more at risk of developing Insomnia. However, a 2020 meta-analysis found that women are more at risk of developing insomnia. This is related to hormonal factors, especially during menopause, the risk is 1.85 times higher due to a decrease in the hormone serotonin, serotonin receptor activity, and tryptophan levels so that women tend to be more prone to depression and anxiety. ${ }^{[17,18]}$ This is assumed because there are more male than female subjects who meet the eligibility criteria and are willing to be research subjects.

The stress level of the subjects found in this study was varied. Stress is reported to be influenced by the higher educational demands of college students (Bachelor, Master, and Doctoral) than the general public. Several studies reveal that the main cause of stress for college students is academic stress. ${ }^{[19,20]}$ Research in Saudi Arabia found more insomnia with stress than without stress. ${ }^{[21]}$ In addition, there was a correlation between stress and workload for lecturers in Malaysia. ${ }^{[22]}$ In a meta-analysis study found that increasing stress can increase sleep disturbances. [23] The difference in stress levels in this study is due to individual coping strategies. Stress coping according to Lazarus's definition is an individual's effort to deal with stressful situations as a result of the burden being faced by making cognitive and behaviour changes to achieve a sense of security. Each individual's reaction to stress varies. Stress coping strategies are divided into emotional coping and problem coping. Emotional 
coping can be in the form of distancing, escape avoiding, self-controlling, accepting responsibility, positive reappraisal and coping with problems, for example, such as planned problem-solving, confrontational coping, seeking social support. ${ }^{[24]}$

Obesity and insomnia have a bidirectional relationship. The BMI characteristics in this study are also in line with research in Indonesia, it was found that insomnia can promote the incidence of obesity, sleep duration of less than 7 hours per day is 7.7 times more likely to be overweight and obese compared to getting enough sleep. ${ }^{[25,26]}$ Research in China found a strong relationship between obstructive sleep apnea (OSA) and insomnia with obesity. ${ }^{[27]}$ On the one side, sleeping only 4 hours can have an effect on decreasing the hormone leptin and increasing the hormone ghrelin. ${ }^{[28]}$ There is a linear relationship between obesity and OSA. Obesity conditions occur in the accumulation of adipose tissue, causing an increase in intrathoracic pressure and eventually hypoxia due to narrowing of the upper respiratory tract. This condition activates the sympathetic nervous system, then increases catecholamine, thereby increasing the state of awakening. In addition, it was found that there was an increase in the hormone leptin in patients with OSA syndrome caused by leptin resistance. ${ }^{[29]}$ On the other side, sleep disturbance causes hormonal imbalances (decreased leptin hormone and increased ghrelin hormone) so that calorie intake increases which is associated with accumulation of triglycerides in adipose tissue and adipocyte hypertrophy resulting in obesity. [28]

The application of sleep hygiene in this study is in line with research in Indonesia that found that the majority of insomnia have poor sleep hygiene. [1] Another study also stated that the frequency of insomnia decreased after sleep hygiene intervention. ${ }^{[30]}$ It is assumed that sleep hygiene is not good for lecturers because lecturers are not only responsible for their role as educators, but also have obligations as students. Based on a case study on graduate college students at the University of Malaysia, it was found that when a person works while studying, there is a risk of adverse effects on physical, psychological health, and decreased academic performance. [31] This of course cannot be separated from work stress which consists of indicators of task and role demands. ${ }^{[9]}$

Alcohol has a sedative effect, but in long-term use it can increase tolerance. ${ }^{[32]}$ Excessive consumption is also associated with poor sleep quality and duration. [33] More subjects in this study did not consume alcohol. This is assumed to occur because the research subjects are health professionals so they already understand the effects of excessive alcohol use on health, so alcohol consumption tends to be low. Insomnia in this study can occur even though not consuming alcohol is supported by research in Colombia which found that alcohol consumption status was not significant for insomnia, but was significantly related to demographic status such as age, gender, and education. ${ }^{[34]}$

Only $30 \%$ of the subjects in this study had coffee consumption habits. Several studies in Indonesia say that the side effect of coffee consumption is dominated by insomnia. [35,36,37] Research on postgraduate students in Indonesia found that coffee consumption more than once a day has an effect on insomnia. [8] Consuming coffee before bed can disrupt sleep significantly, even at 6 hours before bedtime it can reduce sleep duration by more than 1 hour. ${ }^{[38]}$ However, the results of this study were dominated by subjects who did not have coffee consumption habits. These results are supported by research in Indonesia which found that coffee consumption did not show a significant relationship to the quality of sleep patterns. ${ }^{[39,40]}$ It is concluded that coffee does not significantly affect the incidence of insomnia because insomnia itself can appear with increasing age and demands or insomnia caused by other sleep 
hygiene factors. In addition, the effect of caffeine on coffee depends on the level of tolerance for the amount consumed, consumption schedule, and elimination. [41,42]

In this study, all subjects did not have a smoking habit. In line with the research conducted by Rarasta et al. who get a higher proportion of insomniacs who do not smoke compared to smoking habits. ${ }^{[18]}$ However, research in China shows sleep disturbances are more common in smokers than non-smokers. ${ }^{[43]}$ Based on studies of nicotine levels, it has a half-life of about 2 hours and will remain in the blood at significant levels for 6-8 hours after quitting smoking. In long-term use, active smokers will be exposed to large amounts of nicotine for 24 hours every day. Nicotine is addictive so that sudden cessation can result in rewarding behavior that causes somatic and affective symptoms due to neurochemical disorders such as irritability, anxiety, difficulty concentrating, weight gain, and sleep disturbances. ${ }^{[44]}$ This difference is possible because the research subjects are health workers so they already have awareness of the risks of smoking. Other factors that cause insomnia in the subjects of this study are age, education level, lifestyle. ${ }^{[45]}$

\section{CONCLUSION}

The proportion of insomnia among lecturers who continued their postgraduate education at the Faculty of Medicine, Udayana University based on the Insomnia Severity Index questionnaire, found that 10 subjects had mild insomnia (24.4\%), the rest did not experience insomnia. In addition, there were no subjects who experienced moderate or severe insomnia. Characteristics of insomnia in lecturers with mild insomnia obtained with an age range of 26-35 years or the early adult age group which is more common, more male, subjects have varying stress levels, body mass index is the highest with obesity, the dominant subject does not apply good sleep hygiene, the level of coffee and alcohol consumption tends to be low, and there is no smoking habit.

\section{Informed Consent and Patient Details:}

The authors declare that this case report does not contain any personal information that could lead to the identification of the patient(s) and/or volunteers.

\section{Acknowledgement: None}

Conflict of Interest: There are no conflicts of interest to declare by any of the authors of this study.

Source of Funding: This work did not receive any grant from funding agencies in the public, commercial, or not-for-profit sectors.

Ethical Approval: This study has obtained ethical clearance issued by the Research Ethic Commission of Faculty of Medicine, Udayana University, Sanglah General Hospital, Denpasar

\section{REFERENCES}

1. Sayekti N P I W, Hendrati L Y. Analisis Risiko Depresi, Tingkat Sleep Hygiene dan Penyakit Kronis dengan Kejadian Insomnia Pada Lansia. Jurnal Berkala Epidemiologi. 2015; 3(2):181-193.

2. Meadows A. Insomnia. National Sleep Foundation. 2020. Available from https://www.sleepfoundation.org/insomnia.

3. Zucconi M. \& Ferri R. ESRS-sleep medicine textbook: Assessment of sleep disorders and diagnostic procedures. European sleep research society. 2014. Available from https://esrs.eu/wpcontent/uploads/2018/09/ESRS_Sleep_Medi cine_Textbook_Chapter_B1.pdf.

4. Levenso J C, Kay D B, Buysse D J. The Pathophysiology of Insomnia. Chest. 2015; 147(4):1179-1192. Available from doi: 10.1378/chest.14-1617.

5. Kaur H, Spurling B, Bollu P. Chronic Insomnia. Statpearls. 2020. Available from https://www.ncbi.nlm.nih.gov/books/NBK5 26136/. 
6. Bhaskar S, Hemavathy D, Prasad S. Prevalence of chronic insomnia in adult patients and its correlation with medical comorbidities. Journal of Family Medicine and Primary Care. 2016; 5(4):780. Available from doi: 10.4103/22494863.201153.

7. Cao X L, Wang S B, Zhong, B L, Zhang L, Ungvari G S, Ng C H, Li L, Chiu H F K, Lok G K I, Lu J P, Jia F J, Xiang Y T. The prevalence of insomnia in the general population in China: A meta-analysis. PLoS ONE. 2017; 12(2):1-11. Available from doi: 10.1371/journal.pone.0170772.

8. Nurdin M A, Arsin A A, Thaha R M. Kualitas Hidup Penderita Insomnia pada Mahasiswa Quality of Life of Patients with Insomnia to Students. Jurnal MKMI. 2018; 14(2):128-138. Available from doi: 0.30597/mkmi.v14i1.3464.

9. Adiawaty, S. Pandemi Covid-19 dan Kinerja Dosen (Study Kasus Kinerja Dosen pada PT XYZ). ESENSI: Jurnal Manajemen Bisnis. 2020; 23(2):185-191. Available from https://ibn.ejournal.id/index.php/ESENSI/article/view/2 04.

10. Han K S, Kim L, Shim I. Stress and Sleep Disorder. Experimental Neurobiology. 2012; 21(4):141-150. Available from doi: 10.5607/en.2012.21.4.141.

11. Kalmbach D A, Cuamatzi-Castelan A S, Tonnu C V, Tran K M, Andreson J R, Roth T, Drake C L. Hyperarousal and sleep reactivity in insomnia: Current insights. Nature and Science of Sleep. 2018; 10:193201. Available from doi: 10.2147/NSS.S138823.

12. DiBonaventura M, Richard L, Kumar M, Forsythe A, Flores N M, Moline M. The association between insomnia and insomnia treatment side effects on health status, work productivity, and healthcare resource use. PLoS ONE. 2015; 10(10):1-14. Available from doi: 10.1371/journal.pone.0137117.

13. Adila D R, Kurniawan A. Proses Kematangan Emosi Pada Individu Dewasa Awal yang Dibesarkan dengan Pola Asuh Orang Tua Permisif. INSAN: Jurnal Psikologi dan Kesehatan Mental. 2020; 5(1):21. Available from doi: 10.20473/jpkm.v5i12020.21-34.

14. Armstrong D, Dregan A. A populationbased investigation into the self-reported reasons for sleep problems. PLoS ONE.
2014; 9(7):1-6. Available from doi: 10.1371/journal.pone.0101368.

15. Sumedi, T. and Kuswati, A. Pengaruh Senam Lansia Terhadap Penurunan Skala Insomnia Ada Lansia Di Panti Wredha Dewanata Cilacap. Soedirman Journal of Nursing. 2010; 5(1):13-20. Available from doi: 10.20884/1.jks.2010.5.1.252.

16. Erwani, Nofriandi. Faktor - Faktor Yang Berhubungan Dengan Insomnia Pada Lansia Di Puskesmas Belimbing Padang. Jurnal Ilmu Kesehatan. 2017; 1(1):123-132. Available from doi: 10.33757/jik.v1i1.38.

17. Semenova N V, Madaeva I M, Kolesnikova L I. Insomnia and circadian rhythms of melatonin in menopausal women. Acta Biomedica Scientifica. 2018; 3(5):16-21. Available from doi: 10.29413/ABS.20183.5.2.

18. Rarasta M, AR D, Nita S. Prevalensi Insomnia pada Usia Lanjut Warga Panti Werdha Dharma Bakti dan Tresna Werdha Teratai Palembang. Journal Biomedik of Indonesia. 2018; 4(2):1-7. Available from doi: 0.32539/bji.v4i2.7961.

19. Brooke T, Brown M, Orr R, Gough S. Stress and burnout: exploring postgraduate physiotherapy students' experiences and coping strategies. BMC Medical Education. 2020; 20(1):1-11. Available from doi: 10.1186/s12909-020-02360-6.

20. Yikealo D, Yemane B, Karvinen I. The Level of Academic and Environmental Stress among College Students: A Case in the College of Education. Open Journal of Social Sciences. 2018; 06(11):40-57. Available from doi: 10.4236/jss.2018.611004.

21. Albasheer O B, Bahhawi T A, Ryani M A, Arishi A M, Hakami O M, Maashi S M, AlKhairat H K, Alganmy O M, Sahal Y A, Sharif A A, Mahfouz M S. Prevalence of insomnia and relationship with depression, anxiety and stress among Jazan University students: A cross-sectional study. Cogent Psychology. 2020; 7(1):1-10. Available from doi: 10.1080/23311908.2020.1789424.

22. Isa K, Palpanadan S T. Prevalence causes of stress and coping strategies among Malaysian university lecturers. International Journal of Higher Education. 2020; 9(5):312-321. Available from doi: 10.5430/ijhe.v9n5p312.

23. Salari N, Khazaie H, Far A H, Ghasemi H, Mohammadi M, Shohaimi S, Daneshkhah 
A, Paveh B K, Far M H. The prevalence of sleep disturbances among physicians and nurses facing the COVID-19 patients. Globalization and Health. 2020; 16(1):1-14. Available from doi: 10.1186/s12992-02000620-0.

24. Sitepu J M, Nasution M. Pengaruh Konsep Diri Terhadap Coping Stress Pada Mahasiswa Fai Umsu. Intiqad. 2017; 9(1):68-83. Available from doi:10.30596/intiqad.v9i1.1082.

25. Rusmini N P. 2016. Durasi Tidur Dan Obesitas Pada Dewasa Awal Usia 26-35 Tahun Di Wilayah Sidotopo Wetan Surabaya. Adi Husada Nursing Journal. 2016; 2(1):81-84. Available from https://adihusada.ac.id/jurnal/index.php/AH NJ/article/view/38.

26. Damayanti R E, Sumarmi S, Mundiastuti L. Hubungan Durasi Tidur dengan Kejadian Overweight dan Obesitas pada Tenaga Kependidikan di Lingkungan Kampus C Universitas Airlangga. Amerta Nutrition. 2019; 3(2):89-93. Available from doi: 10.2473/amnt.v3i2.2019.89-93.

27. Tan X, Alen M, Cheng S M, Mikkola T M, Tenhunen J, Lyytikainen A, Wiklund P, Cong F, Saarinen A, Tarkka I, Partinen M, Cheng S. Associations of disordered sleep with body fat distribution, physical activity and diet among overweight middle-aged men. Journal of Sleep Research. 2015; 24(4):414-424. Available from doi: 10.1111/jsr.12283.

28. Kim T W, Jeong J H, Hong S C. The impact of sleep and circadian disturbance on hormones and metabolism. International Journal of Endocrinology. 2015. Available from doi: 10.1155/2015/591729.

29. Jehan S, Zizi F, Pandi-Perumal S R, Wall S, Auguste E, Myers A K, Jean-Louis G, McFarlane S I. Obstructive Sleep Apnea and Obesity: Implications for Public Health. Sleep Medicine and Disorders. 2017; 1(4):00019. Available from https://www.ncbi.nlm.nih.gov/pmc/articles/ PMC5836788/.

30. Nadyatama M A. Pengaruh Terapi Aktivitas Sleep Hygiene terhadap Kualitas Tidur Pada Lansia di Balai Pelayanan Sosial Tresna Werdha Unit Budi Luhur Yogyakarta. Yogyakarta: Universitas Aisyiyah Yogyakarta; 2018.

31. Tumin, Faizuddin A. The Experiences of Working While Studying: A Case Study of
Postgraduate Students at International Islamic University Malaysia. Academia. 2017; 1-9. Available from https://www.researchgate.net/publication/32 8379557.

32. Lin C L, Sun J C, Lin M C P, Chung C H, Chien W C. Risk of alcohol use disorders in patients with insomnia: A population-based retrospective cohort study. Elsevier Inc. 2020; 89:123-128. Available from doi: 10.1016/j.alcohol.2020.08.008.

33. Park S Y, Oh M K, Lee B S, Kim H G, Lee W J, Lee J H, Lim J T, Kim J Y. The effects of alcohol on quality of sleep. Korean Journal of Family Medicine. 2015; 36(6):294-299. Available from doi: 10.4082/kjfm.2015.36.6.294.

34. Vinson D C, Manning B K, Galliher J M, Dickinson L M, Pace W D, Turner B J. Alcohol and sleep problems in primary care patients: A report from the AAFP national research network. Annals of Family Medicine. 2010; 8(6):484-492. Available from doi: 10.1370/afm.1175.

35. Liveina, Artini I G A. Pola Konsumsi Dan Efek Samping Minuman Mengandung Kafein Pada Mahasiswa Program Studi Pendidikan Dokter Fakultas Kedokteran Universitas Udayana. E-Jurnal Medika Udayana. 2014; 3(4):1-12. Available from https://ojs.unud.ac.id/index.php/eum/article/ view/8507.

36. Maulidan M, Alam T S. Insomnia dan Kecemasan pada Masyarakat yang Mengkonsumsi Kopi. JIM FKEP. 2018; 3(2):241-247. Available from http://jim.unsyiah.ac.id/FKep/article/view/8 436.

37. Wahyuni I, Yusuf S, Magga E. Pengaruh Konsumsi Kopi Terhadap Tekanan Darah Dan Insomnia Pada Mahasiswa Universitas Muhammadiyah. Jurnal Ilmiah Manusia dan Kesehatan. 2020; 3(3):395-402. Available from https://doi.org/10.31850/makes.v3i3.368.

38. Drake C, Roehrs T, Shambroom J, Roth T. Caffeine effects on sleep taken 0,3 , or 6 hours before going to bed. Journal of Clinical Sleep Medicine. 2013; 9(11):11951200. Available from doi: 10.5664/jcsm.3170.

39. Purdiani M. Hubungan Penggunaan Minuman Berkafein Terhadap Pola Tidur dan Pengaruhnya pada Tingkah Laku Mahasiswa/I Universitas Surabaya Monica 
Ni Putu Kostarika Melia Daradila et.al. Proportion and characteristics of insomnia among lecturers continuing postgraduate education at the faculty of Medicine Udayana University.

Purdiani. Calyptra: Jurnal Ilmiah Mahasiswa Universitas Surabaya. 2014; 3(1):1-15. Available from doi: https://journal.ubaya.ac.id/index.php/jimus/a rticle/view/1508.

40. Faridah U, Kusumawati D, Rahayu S, Wahab D. Hubungan Kebiasaan Mengkonsumsi Kopi Dengan Gejala Gangguan Tidur Pada Lansia Di Desa Tempuran Demak 2018. University Research Colloqium. 2021; 228-241. Available from https://repository.urecol.org/index.php/proc eeding/article/view/1328.

41. Alsabri S G, Mari W O, Younes S, Alsadawi M A, Oroszi T L. Kinetic and Dynamic Description of Caffeine. Journal of Caffeine and Adenosine Research. 2018; 8(1):3-9. Available from doi: 10.1089/caff.2017.0011.

42. O'callaghan F, Muurlink O, Reid N. Effects of caffeine on sleep quality and daytime functioning. Risk Management and Healthcare Policy. 2018; 11:263-271. Available from doi: 10.2147/RMHP.S156404.

43. Liao Y, Xie L, Chen X, Kelly B C, Qi C, Pan C, Yang M, Hao W, Liu T, Tang J.
Sleep quality in cigarette smokers and nonsmokers: Findings from the general population in central China. BMC Public Health. 2019; 19(1), 1-9. Available from doi: 10.1186/s12889-019-6929-4.

44. Benowitz N L, Hukkanen J, Jacob P. Nicotine chemistry, metabolism, kinetics and biomarkers. Handbook of experimental pharmacology. 2009; 192:29-60. Available from https://doi.org/10.1007/978-3-54069248-5_2.

45. Susanti L. Faktor-Faktor Yang Mempengaruhi Kejadian Insomnia di Poliklinik Saraf RS DR. M. Djamil Padang. Jurnal Kesehatan Andalas. 2015; 4(3):951956. Available from doi: 10.25077/jka.v4i3.391.

How to cite this article: Ni Putu Kostarika Melia Daradila, Desak Ketut Indrasari Utami, Kumara Tini et.al. Proportion and characteristics of insomnia among lecturers continuing postgraduate education at the faculty of Medicine Udayana University. International Journal of Research and Review. 2021; 8(12): 438-446. DOI: https://doi.org/10.52403/ijrr. 20211254 